\title{
Efficient Voltage Regulation with Modified Hybrid SEPIC DC-DC-Converter
}

\author{
Md. Ali Azam Khan ${ }^{1}$ and Mohammad Ali Choudhury ${ }^{2}$ \\ ${ }^{1}$ Department of EECE, MIST, Dhaka, Bangladesh \\ ${ }^{2}$ Department ofEEE,BUET,Dhaka, Bangladesh
}

\begin{abstract}
Switch mode dc-dc converters are attractive for their small size, ease of control and efficient power conversion. Output voltage is regulated by duty cycle control of semiconductor switch of switch mode dc-dc converters. The voltage gain and efficiency of practical switching regulators deviate from ideal values at extreme duty cycles. Also, desired gain /attenuation is not achievable at high/low duty cycles. In applications where high gain or high attenuation of voltage is desired with acceptable energy conversion efficiency, hybrid dc-dc switching converters are used. Hybrid dc-dc converters are combination of voltage multiplier/division circuit with appropriate SMPS circuits. By incorporating voltage multiplier/division cell with conventional SEPIC converters, desired voltage gain (either very low or very high) may be achieved at acceptable energy conversion efficiency. In the present work with an aim to attain very high voltage gain by conventional SEPIC topologies, a new voltage multiplier cell consisting of multiple inductors and diodes is proposed.
\end{abstract}

\section{Introduction}

Modern power electronic switches can operate at high frequencies. The high frequency DC-DC chopperconverters are known as switch mode power supplies (SMPS). SMPS are extensively used as power supplies of computers and electronic equipment. According to the type of voltage regulation (step-down/step-up/step-updown) SMPS has three basic (Buck, Boost and BuckBoost/Cuk/Sepic) and many derived configurations. The voltage regulation is achieved by duty cycle (D) control of the switching signal of the semiconductor switch of the SMPS. In a practical SMPS, the efficiency and the voltage-gain are function of the duty cycle D. Each type of SMPS has high value of efficiency for limited range of voltage gain (within a range of duty cycle D). In case of extreme gains (either high or low), hybrid SMPS converters may be used to maintain high conversion efficiency. Hybrid SMPS converters are combination of voltage multiplier/divider circuits with appropriate SMPS circuits. In this Thesis work the SEPIC, the hybrid boost dc-dc converter with two inductors, the hybrid proposed SEPIC converter with two inductors and the proposed hybrid SEPIC dc-dc converter with three inductors are studied by simulation at variable duty cycles.

\section{Multiple inductor multiplier cell}

Proposed two inductor cell for SEPIC dc-dc hybrid converter is shown in Figure-1. The circuit of Figure-2 takes the form of Figure-a when the switch is ON. Currents flow through the inductors according to current division rule and rises with time. Instantaneous voltage across the inductor $\mathrm{L}_{1}$ and $\mathrm{L}_{2}$ are $v_{L 1}=L_{1} \frac{d i_{L 1}}{d t}$ and $v_{L 2}=L_{2} \frac{d i_{l 2}}{d t}$ respectively. If the two inductors have half the value of the inductor of single inductor conventional dc-dc converter, then $i_{L_{2}}$ and $i_{L_{1}}$ will be larger than $i_{\mathrm{L}}$ of the $\mathrm{L}$ of conventional dc-dc converter. As a result $v_{L_{2}}$ and $v_{L_{1}}$ will be higher than $v_{\mathrm{L}}$ of conventional dc-dc converter. When the switch of the proposed cell turns OFF, $\mathrm{V}_{\mathrm{dc}}+v_{L_{1}}$ or $\mathrm{V}_{\mathrm{dc}}+v_{L_{2}}$ appear across the switch providing the boost voltage to the next stage of the converter. Since $v_{L_{1}}$ or $v_{L_{2}}$ stage of the converter,

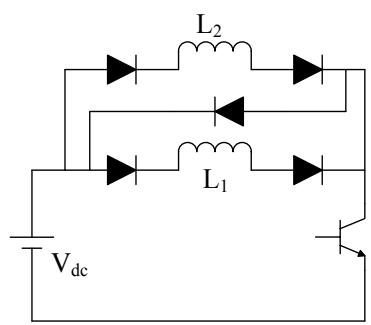

Figure1 . Proposed inductor cell for SEPIC converter. 


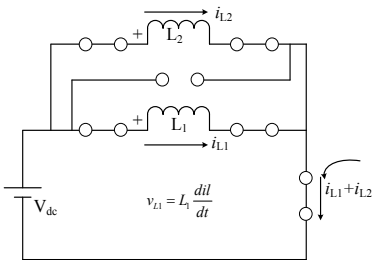

(a)Circuit for Figure1.(when switch is $\mathrm{ON}$ )

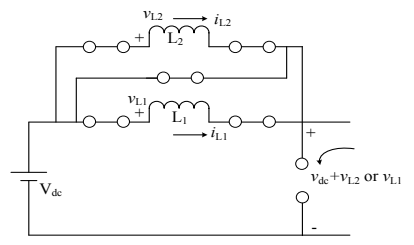

(b) Circuit for Figure1.(when switch is OFF)

Figure 2 Circuit of Figure 1 when is turns $\mathrm{ON}$ and OFFis higher than $\mathrm{v}_{1}$ of conventional dc-dc converter, the proposed cell will provide higher Boost voltage to the next stage of the dc-dc converter at a lower duty cycle then the conventional dc-dc SEPIC converter. The proposed cell is different than the SEPIC cell of Figure 2 and 3 made of two inductors of reference [1].It can be multiplied several times as shown in Figure 4 and 5.

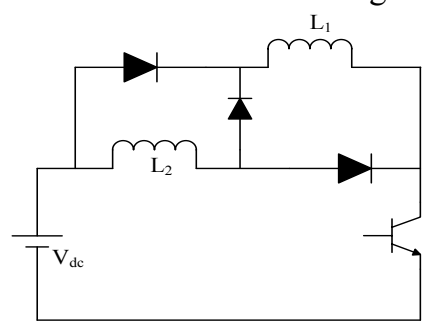

Figure 2. SEPIC cell made two inductors as reported in reference [1].

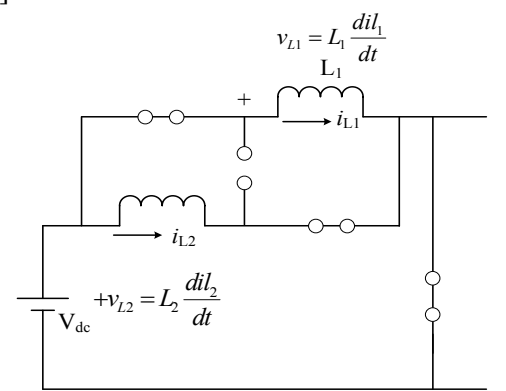

(a) SEPIC cell of Figure 2.(when switch is ON)

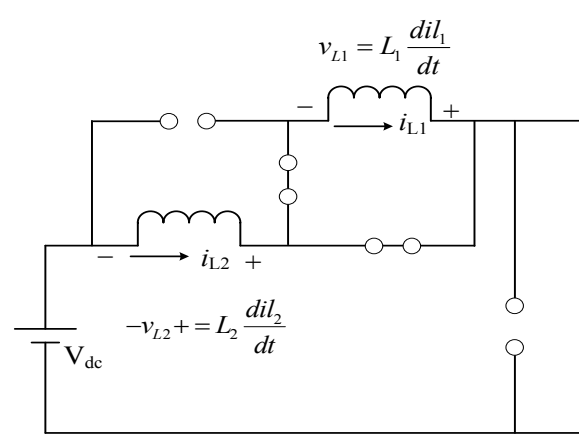

(b) SEPIC cell of Figure 2.(when switch is OFF)

Figure 3. SEPIC cell made of two inductors as reported in reference [1] with switch ON and OFF. Proposed three and four inductor cells

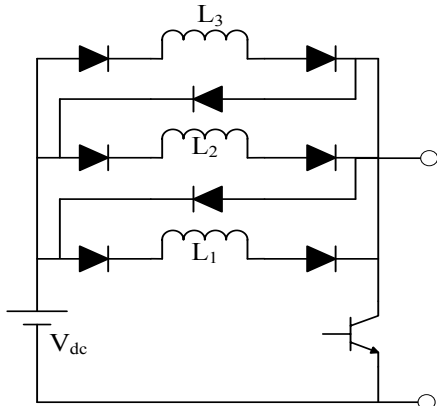

Figure 4. Proposed SEPIC cell with three inductors.

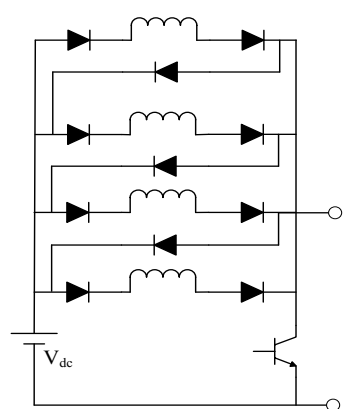

Figure 5. Proposed SEPIC cell with four inductors.

\section{Results and discussions}

The SEPIC dc-dc convertor, the hybrid sepic[1]dc-dc converter with two inductors, the hybrid proposed sepic converter with two inductors and the proposed hybridsepic dc-dc converter with three inductors are studied by simulation at variable duty cycles. The total inductors in all the circuits are kept at $1 \mathrm{mH}$ for the purpose of comparison on the same component value. The conventional SEPIC circuit is shown in figure 6 and its typical waveforms are shown in figure 7. The SEPIC hybrid boost circuit of reference [1] is shown in figure 10 and its typical waveforms is shown in Figure 11. The proposed SEPIC hybrid circuit with two and three inductor cells are shown in Figures 14 and 18 respectively. Typical waveforms of Figures 14 and 18 are shown in Figures 15 and 19 respectively. The input voltage, output voltage, voltage gain, input power, output power and efficiency are tabulated in tables 2-5 and depicted in graphs of Figure 8-9, Figure 12-13, Figure 16-17, Figure 20-21respectively. Table 1.A compares the results of four configurations for voltage gain of 5.1 in the first row, which indicate that for $1 \mathrm{mH}$ total inductor the voltage gain 5.1 takes place at $0.8,0.5,0.6$ and .4 duty cycle for normal SEPIC, hybrid SEPIC [1], proposed hybrid SEPIC of 2 inductors and proposed hybrid of 3 inductor circuit. The efficiency of the [1]SEPIC hybrid circuit is higher than normal, proposed hybrid circuit for two inductors and also for 3 inductor circuit.

Also in the second row of the table 1.A it is evident that voltage gain of the multiple inductors can be made higher than any other topology. The increase of inductor number keeping the total inductor value same is not possible in the hybrid circuit of the paper[1]. 
Table 1.A comparison of normal SEPIC, SEPIC hybrid topologyof[1], proposed sepic hybrid topology with two inductor, proposed topology with three inductor

\begin{tabular}{|c|c|c|c|c|c|}
\hline \multicolumn{3}{|c|}{ Normal SEPIC } & \multicolumn{3}{c|}{$\begin{array}{c}\text { SEPIC Hybrid of [1] with } \\
\text { 2 Inductor }\end{array}$} \\
\hline $\begin{array}{c}\text { Duty } \\
\text { cycl } \\
\text { e }\end{array}$ & $\begin{array}{c}\text { Voltag } \\
\text { e Gain }\end{array}$ & $\begin{array}{c}\text { Efficienc } \\
\text { y } \\
\%\end{array}$ & $\begin{array}{c}\text { Duty } \\
\text { cycl } \\
\text { e }\end{array}$ & $\begin{array}{c}\text { Voltag } \\
\text { e Gain }\end{array}$ & $\begin{array}{c}\text { Efficienc } \\
\text { y } \\
\%\end{array}$ \\
\hline 0.8 & 5.1 & 90 & 0.5 & 5.145 & 96.11 \\
\hline .875 & 6.4 & 79.78 & .875 & 10.32 & 67.01 \\
\hline
\end{tabular}

Table 1.A (Continued)

\begin{tabular}{|c|c|c|c|c|c|}
\hline \multicolumn{2}{|c|}{$\begin{array}{l}\text { Sepic Hybrid of Proposed } \\
\text { Topology with 2 Inductor }\end{array}$} & \multicolumn{3}{|c|}{$\begin{array}{c}\text { SEPIC Hybrid of } \\
\text { Proposed Topology with } 3 \\
\text { Inductor }\end{array}$} \\
\hline $\begin{array}{c}\text { Duty } \\
\text { cycle }\end{array}$ & $\begin{array}{c}\text { Voltag } \\
\text { e Gain }\end{array}$ & $\begin{array}{c}\text { Efficienc } \\
\text { y } \\
\%\end{array}$ & $\begin{array}{c}\text { Duty } \\
\text { cycle }\end{array}$ & $\begin{array}{c}\text { Voltag } \\
\text { e Gain }\end{array}$ & $\begin{array}{c}\text { Efficienc } \\
\text { y } \\
\%\end{array}$ \\
\hline
\end{tabular}

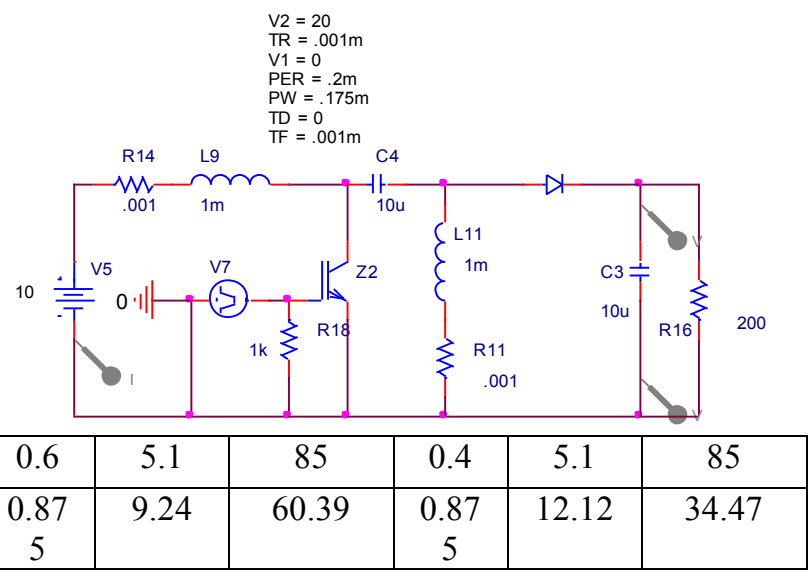

Figure 6. SEPIC DC-DC converter.

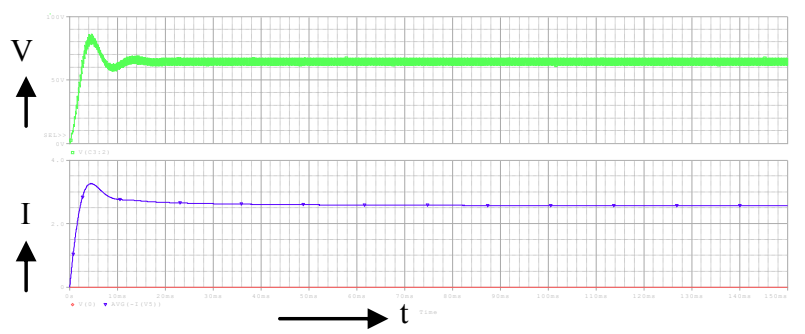

Figure 7. Typical Waveform Sepic DC-DC Converter of Figure 6.

Table 2. Performance of Sepic DC-DC converter circuit of figure 6 .

\begin{tabular}{|c|c|c|c|c|c|c|c|c|}
\hline $\begin{array}{c}\text { Duty } \\
\text { Cycle }\end{array}$ & $\begin{array}{c}\mathrm{V}_{\text {in }} \\
(\mathrm{V})\end{array}$ & $\begin{array}{c}\mathrm{I}_{\text {in }} \\
(\mathrm{A})\end{array}$ & $\begin{array}{c}\text { Vout } \\
(\mathrm{V})\end{array}$ & $\begin{array}{c}\text { Iout } \\
(\mathrm{A})\end{array}$ & $\begin{array}{c}\text { Pin } \\
(\mathrm{W})\end{array}$ & $\begin{array}{c}\text { Pout } \\
(\mathrm{W})\end{array}$ & $\begin{array}{c}\text { Voltage } \\
\text { gain }\end{array}$ & $\begin{array}{c}\text { Efficiency } \\
\text { in } \\
\text { percentage }\end{array}$ \\
\hline 0.125 & 10 & 0.04 & 8.99 & 0.04 & 0.41 & 0.39 & .89 & 95.12 \\
\hline 0.25 & 10 & 0.15 & 17.17 & 0.08 & 1.55 & 1.52 & 1.71 & 98.06 \\
\hline 0.375 & 10 & 0.29 & 23.50 & 0.11 & 2.94 & 2.74 & 2.35 & 93.19 \\
\hline 0.50 & 10 & 0.52 & 31.17 & 0.15 & 5.22 & 4.83 & 3.11 & 92.52 \\
\hline 0.625 & 10 & 0.82 & 39.53 & 0.19 & 8.21 & 7.51 & 3.95 & 91.47 \\
\hline 0.75 & 10 & 1.21 & 46.78 & 0.23 & 12.10 & 10.89 & 4.67 & 90.00 \\
\hline 0.875 & 10 & 2.57 & 64.25 & 0.32 & 25.77 & 20.56 & 6.42 & 79.78 \\
\hline
\end{tabular}

\section{Voltage gain vs Duty Cycle}

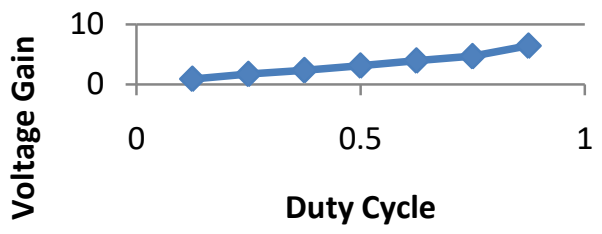

Figure 8.Voltage gain vs duty cycle curve of Sepic DC-DC converter of figure 6 .

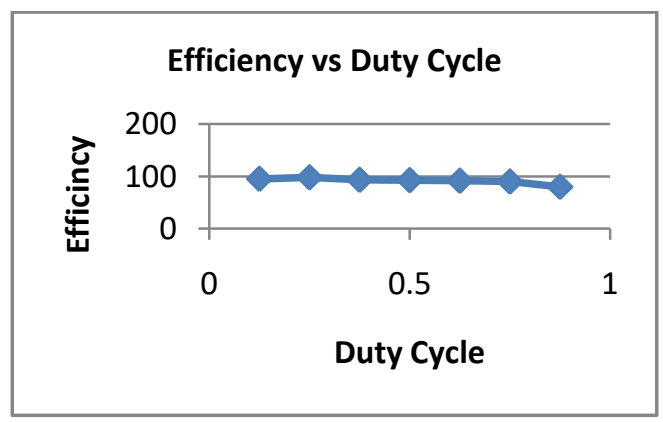

Figure 9. Efficiency vsduty cycle curve of Sepic DC-DC converter of figure6.

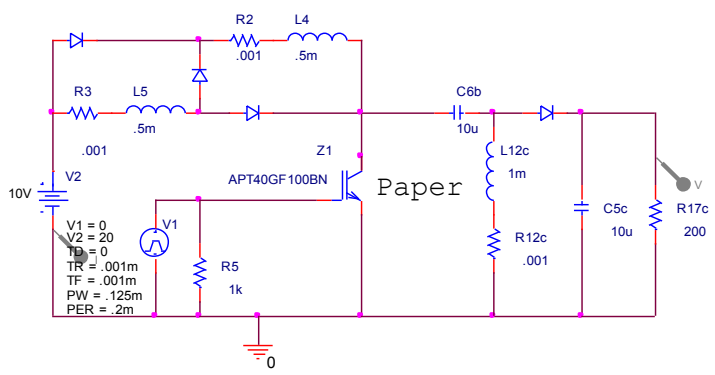

Figure 10. SEPIC hybrid DC-DC converter [1].

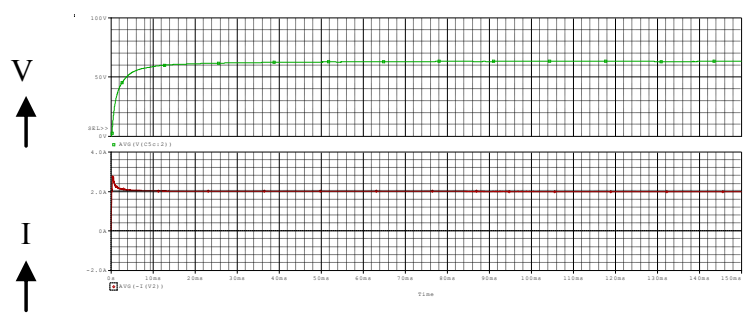

Figure 11. Typical waveform $\mathrm{S}^{\mathrm{t}}$ epichybrid DC-DC converter of figure 10 .

Table 3. Performance of sepic hybrid DC-DC converter of figure 10.

\begin{tabular}{|c|c|c|c|c|c|c|c|c|}
\hline $\begin{array}{l}\text { Duty } \\
\text { Cycl } \\
\text { e }\end{array}$ & $\begin{array}{l}V_{\text {in }} \\
(V \\
\text { ) }\end{array}$ & $\begin{array}{l}\mathbf{I}_{\text {in }} \\
\text { (A) }\end{array}$ & $\begin{array}{l}V_{\text {out }} \\
\text { (V) }\end{array}$ & $\begin{array}{c}\mathbf{I}_{\text {out }}(\mathbf{A} \\
)\end{array}$ & $\begin{array}{l}\mathbf{P}_{\text {in }} \\
(\mathrm{W})\end{array}$ & $\begin{array}{l}\mathbf{P}_{\text {out }} \\
(\mathbf{W})\end{array}$ & $\begin{array}{l}\text { Voltag } \\
\text { e gain }\end{array}$ & $\begin{array}{c}\text { Efficiency } \\
\text { in } \\
\text { percentag } \\
\text { e }\end{array}$ \\
\hline $\begin{array}{c}0.12 \\
5\end{array}$ & 10 & $\begin{array}{c}0.1 \\
4\end{array}$ & 6.08 & 0.08 & 1.4 & 1.29 & 1.60 & 92.34 \\
\hline 0.25 & 10 & $\begin{array}{c}0.3 \\
8\end{array}$ & 27.09 & 0.13 & 3.83 & 3.66 & 2.70 & 5.80 \\
\hline $\begin{array}{c}0.37 \\
5\end{array}$ & 10 & $\begin{array}{c}0.7 \\
9\end{array}$ & 39.6 & 0.19 & 7.91 & 7.84 & 3.96 & 99.12 \\
\hline 0.5 & 10 & $\begin{array}{c}1.3 \\
7\end{array}$ & 51.45 & 0.25 & $\begin{array}{c}13.7 \\
7\end{array}$ & $\begin{array}{c}13.2 \\
3\end{array}$ & 5.14 & 96.11 \\
\hline 0.62 & 10 & $\begin{array}{c}2.0 \\
6\end{array}$ & 62.8 & 0.31 & 20.6 & $\begin{array}{c}19.7 \\
1\end{array}$ & 6.28 & 95.72 \\
\hline
\end{tabular}




\begin{tabular}{|c|c|c|c|c|c|c|c|c|}
\hline 0.75 & 10 & $\begin{array}{c}2.9 \\
8\end{array}$ & 72.33 & 0.36 & 29.8 & $\begin{array}{c}26.1 \\
5\end{array}$ & 7.23 & 87.77 \\
\hline $\begin{array}{c}0.87 \\
5\end{array}$ & 10 & $\begin{array}{c}7.9 \\
5\end{array}$ & $\begin{array}{c}103.2 \\
2\end{array}$ & 0.51 & 79.5 & 53.2 & 10.32 & 67.01 \\
\hline
\end{tabular}

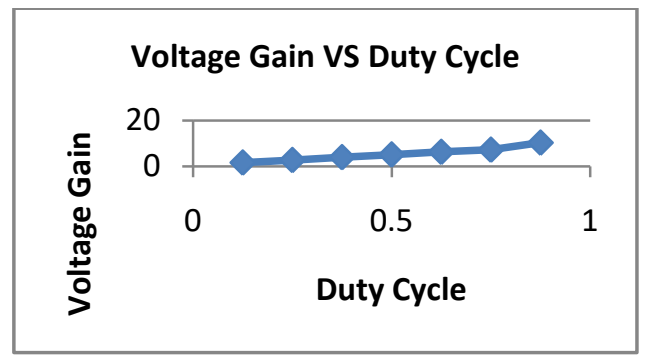

Figure 12. Voltage gain vs duty cycle curve of hybrid sepicDCDC converter of figure 10.

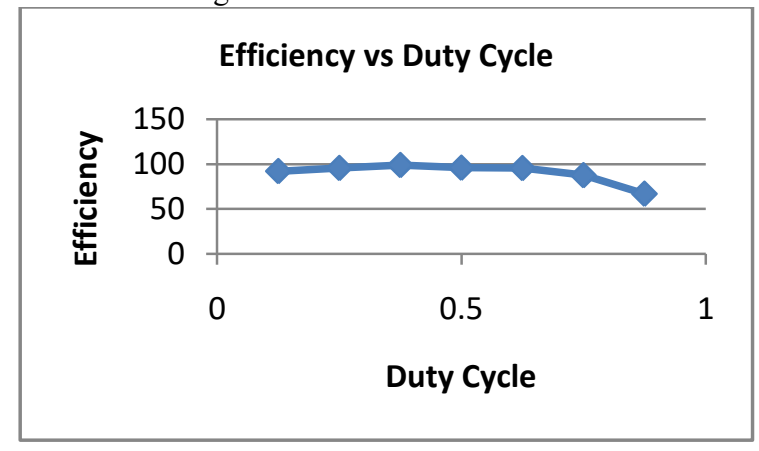

Figure 13. Efficiency vsduty cycle curve of hybridsepic DCDC converter of figure 10.

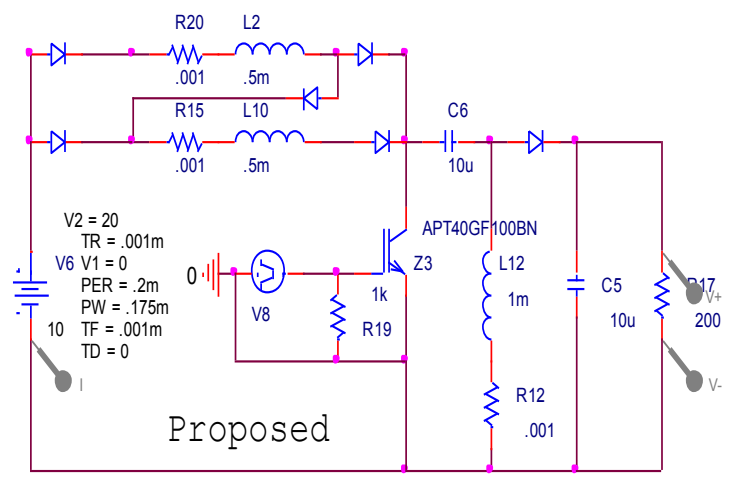

Figure 14. SEPIC hybrid DC-DC converter (proposed).

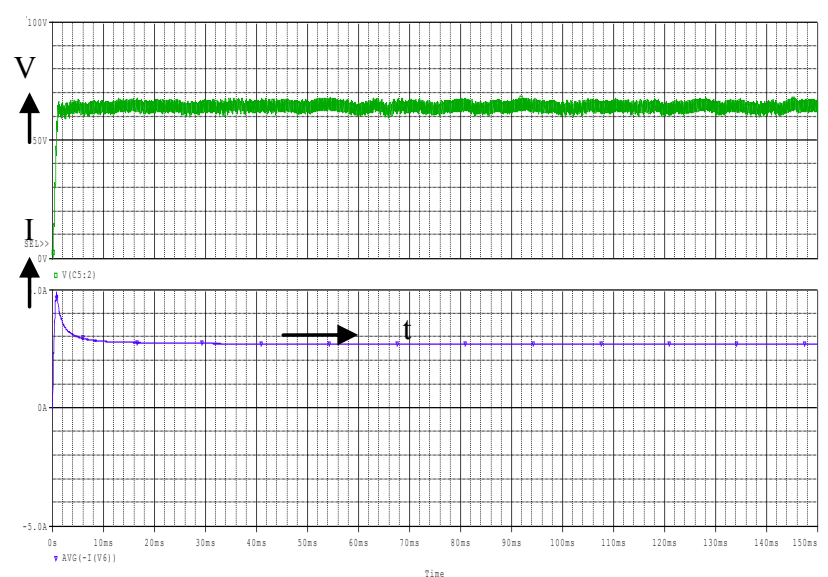

Figure 15. Typical waveform SEPIC hybrid DC-DC converter of figure-14.
Table 4. Performance of Sepichybrid DC-DC converter of figure-14.

\begin{tabular}{|c|c|c|c|c|c|c|c|c|}
\hline $\begin{array}{c}\text { Duty } \\
\text { Cycle }\end{array}$ & $\begin{array}{c}\mathrm{V}_{\text {in }} \\
(\mathrm{V})\end{array}$ & $\begin{array}{c}\mathrm{I}_{\text {in }} \\
(\mathrm{A})\end{array}$ & $\begin{array}{c}\mathrm{V}_{\text {out }} \\
(\mathrm{V})\end{array}$ & $\begin{array}{c}\mathrm{I}_{\text {out }} \\
(\mathrm{A})\end{array}$ & $\begin{array}{c}\mathrm{P}_{\text {in }} \\
(\mathrm{W})\end{array}$ & $\begin{array}{c}\mathrm{P}_{\text {out }} \\
(\mathrm{W})\end{array}$ & $\begin{array}{c}\text { Voltage } \\
\text { gain }\end{array}$ & $\begin{array}{c}\text { Efficiency } \\
\text { in } \\
\text { percentage }\end{array}$ \\
\hline 0.125 & 10 & 0.10 & 14.04 & 0.07 & 1.02 & 0.98 & 1.40 & 90.42 \\
\hline 0.25 & 10 & 0.31 & 22.96 & 0.11 & 3.17 & 2.63 & 2.29 & 83.14 \\
\hline 0.375 & 10 & 0.69 & 35.29 & 0.17 & 6.99 & 6.22 & 3.52 & 89.08 \\
\hline 0.5 & 10 & 1.18 & 45.15 & 0.22 & 11.8 & 10.19 & 4.51 & 86.37 \\
\hline 0.625 & 10 & 1.86 & 56.13 & 0.28 & 18.6 & 15.75 & 5.61 & 84.69 \\
\hline 0.75 & 10 & 2.84 & 64.14 & 0.32 & 28.4 & 20.56 & 6.41 & 72.42 \\
\hline 0.875 & 10 & 7.08 & 92.48 & 0.46 & 70.8 & 42.76 & 9.24 & 60.39 \\
\hline
\end{tabular}

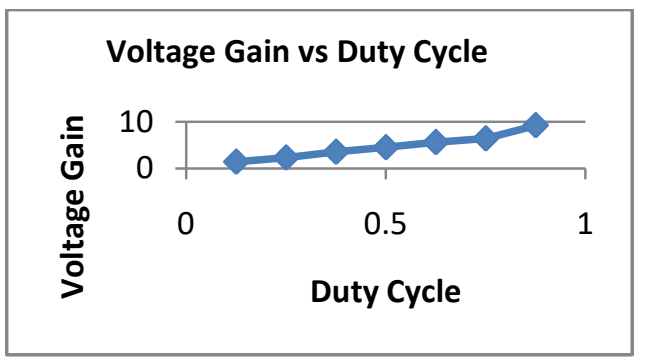

Figure 16. Voltage gain vs duty cycle curve of hybridSepic DC-DC converter of figure 14.

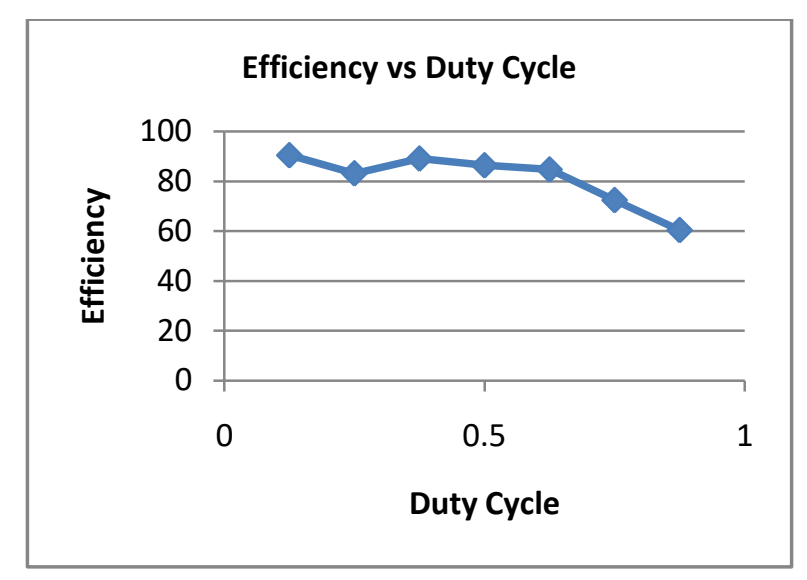

Figure 17. Efficiency vsduty cycle curve of hybridSepic DCDC converter of figure 14.

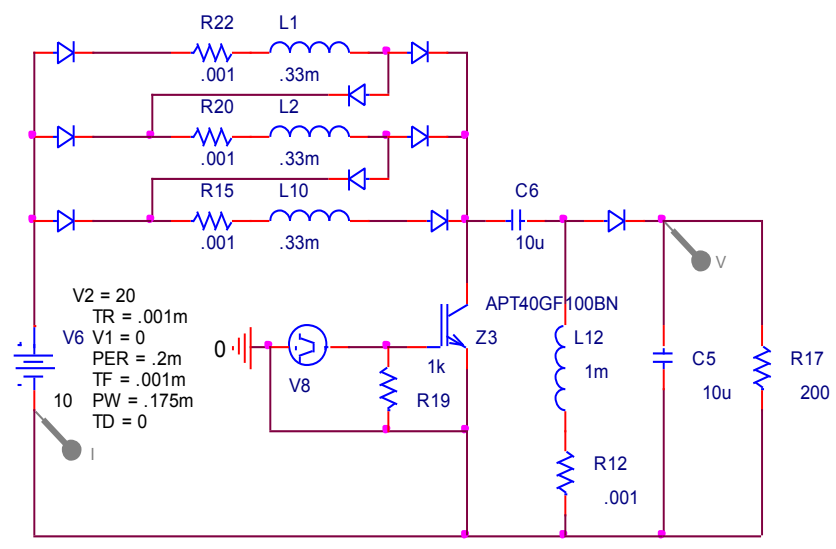

Figure 18. SEPIC hybrid DC-DC converter. 


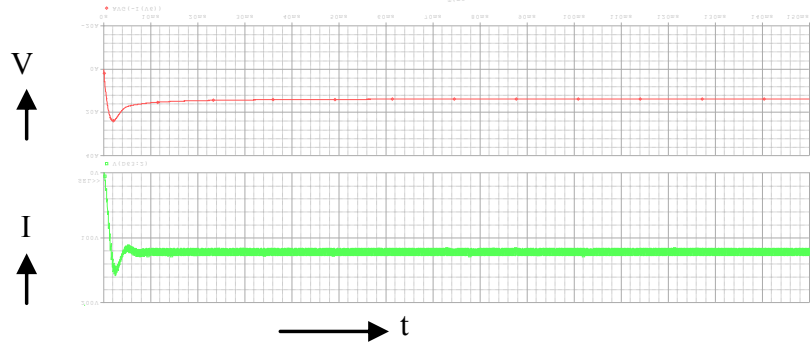

Figure 19. Typical wavefromsepic hybrid DC-DC converter of figure 18.

Table 5. Performance ofsepichybrid DC-DC converter of figure 18 .

\begin{tabular}{|c|c|c|c|c|c|c|c|c|}
\hline $\begin{array}{c}\text { Duty } \\
\text { Cycle }\end{array}$ & $\begin{array}{c}\text { Vin } \\
(\mathrm{V})\end{array}$ & $\begin{array}{c}\text { Iin } \\
(\mathrm{A})\end{array}$ & $\begin{array}{c}\text { Vout } \\
(\mathrm{V})\end{array}$ & $\begin{array}{c}\text { Iout } \\
(\mathrm{A})\end{array}$ & $\begin{array}{c}\text { Pin } \\
(\mathrm{W})\end{array}$ & $\begin{array}{c}\text { Pout } \\
(\mathrm{W})\end{array}$ & $\begin{array}{c}\text { Voltage } \\
\text { gain }\end{array}$ & $\begin{array}{c}\text { Efficiency } \\
\text { in } \\
\text { percentage }\end{array}$ \\
\hline 0.125 & 10 & 0.24 & 19.30 & 0.09 & 2.44 & 1.85 & 1.93 & 75.81 \\
\hline 0.25 & 10 & 0.68 & 31.50 & 0.15 & 6.80 & 4.94 & 3.15 & 80.45 \\
\hline 0.375 & 10 & 1.33 & 48.44 & 0.242 & 13.30 & 11.72 & 4.84 & 88.12 \\
\hline 0.50 & 10 & 2.34 & 61.06 & 0.30 & 23.44 & 18.62 & 6.10 & 79.43 \\
\hline 0.625 & 10 & 3.73 & 74.27 & 0.37 & 37.33 & 27.55 & 7.42 & 73.80 \\
\hline 0.75 & 10 & 6.95 & 85.84 & 0.42 & 69.55 & 36.82 & 8.58 & 52.94 \\
\hline 0.875 & 10 & 20.70 & 121.22 & 0.60 & 207.07 & 73.45 & 12.12 & 34.47 \\
\hline
\end{tabular}

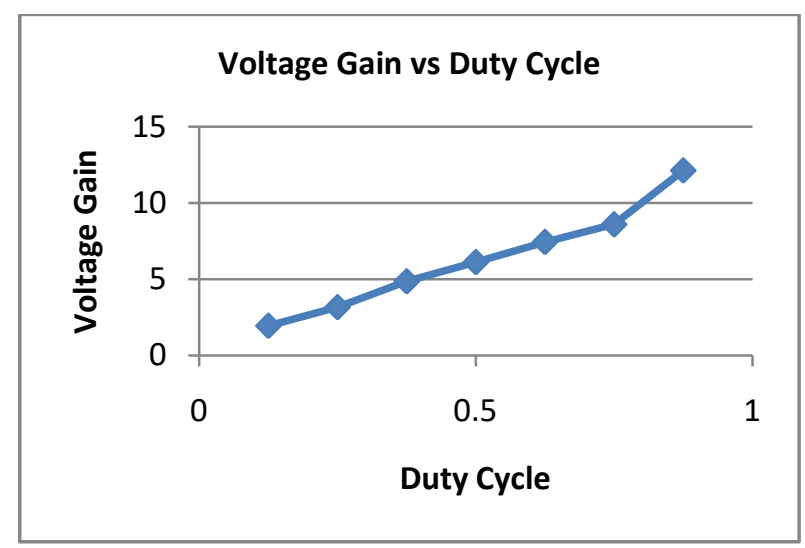

Figure 20. Voltage gain vs duty cycle curve of hybrid SEPIC DC-DC converter of figure 18.

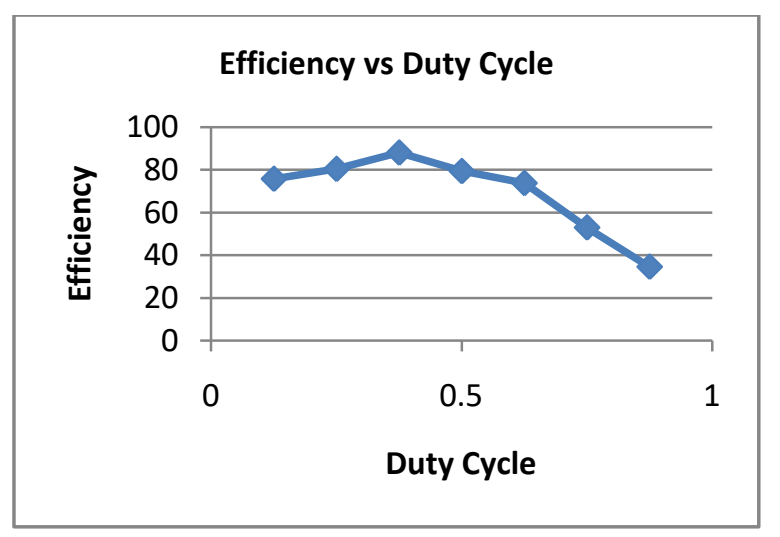

Figure 21. Efficiency vsduty cycle curve of hybrid Sepic DCDC converter of figure 18.

\section{Conclusions}

The proposed cellis investigated with conventional SEPIC dc-dc converters topologies with expected result of attaining same voltage gain than conventional dc-dc converter counterpart with higher efficiencies at lower duty cycle. The dc-dc converters were found to behave similarly for voltage gain and efficiency at higher duty cycles. It was also observed that the voltage gain of these converters in hybrid mode operations can be varied widely to higher gain levels than conventional converters.

\section{References}

1. B. Axelrod, Y. Berkovich, A. Ionovici: "Switchedcapacitor/ switched-inductor structures for getting transformerless hybrid DC- DC PWM converters", IEEE Transactions on Circuits and Systems I. vol. 55, no. 2, pp. 687-696. (2008)

2. [2] A. Kishon Robert, C. Baskaran "Single switch high stepup dc-dc converters with voltage multiplier cell", International Journal of Advanced Trends in Computer Science and Engineering, Vol.2, No.2, Pages : 95-100 (2013) Special Issue of NCRTECE 2013 - Held during 8-9 February, 2013 in SMK Fomra Institute of Technology, OMR, Thaiyur, Kelambakkam, Chennai pp 95-100, (2013)

3. A. Gopi and R. Saravanakumar, "High Boost Isolated DC-DC Converter with Controller."World Applied Sciences Journal 23 (4): pp. 486-494, 2013 ISSN 1818-4952, (2013)

4. Daniel W Hart., "Power Electronics", McGraw Hill, (2010)

5. R. W. Erickson, "Fundamental of Power Electronics", Chapman and Hall, USA, (1997)

6. M. H. Rashid, "Power Electronics Handbook", Academic Press, USA, (2001)

7. Timothy Skvarenina, "The Power Electronics Handbook", CRC Press (2002)

8. Fang Lin Luo and Hong Ye, "Advanced MultiQuadrant DC/DC Converters", CRC Press, (2006)

9. Keng C Wu., "Switch Mode Power Converter", Elsevier Academic Press, (2006)

10. Dorin O. Neaesu, "Power Switching Converters", CRC Press (2006) 